wania rządu są większe w odniesieniu do przyszłych nominacji. Te zmiany wskazują, że wreszcie Unia Europejska będzie mogła wykorzystać wszystkie możliwości, jakie daje Wspólna Polityka Zagraniczna i Bezpieczeństwa.

Zagadnienia te stały się tematem kolejnej, drugiej już publikacji Beaty Przybylskiej-Maszner i Anny Potyrały z cyklu „Leksykon integracji europejskiej”. Tym razem dotyczy ona Wspólnej Polityki Zagranicznej i Bezpieczeństwa i Europejskiej Polityki Bezpieczeństwa i Obrony. To pierwsze tego typu opracowanie, które w sposób szczegółowy i kompleksowy przedstawia zadania, kompetencje, instytucje, programy i działania w obu wymienionych obszarach. Warto podkreślić aktualność publikacji, która uwzględnia najnowsze rozwiązania w obszarze polityki UE wobec państw trzecich. Uzasadnionym posunięciem była rezygnacja $\mathrm{z}$ haseł dotyczących podstaw integracji europejskiej, co pozwoliło na dokładniejsze omówienie zagadnień koncentrujących się wokół tematu publikacji. Czytelny układ haseł w porządku alfabetycznym ułatwia odnalezienie poszukiwanego terminu, a odsyłacze pozwalają poszerzyć wiedzę o niezbędne informacje związane z wyjaśnianym zagadnieniem. Interesującym pomysłem jest umieszczenie w pracy zestawienia wybranych spraw ${ }^{2}$ skierowanych do Sądu Pierwszej Instancji i Europejskiego Trybunału Sprawiedliwości w obszarze Wspólnej Polityki Zagranicznej i Bezpieczeństwa - walka $z$ terroryzmem oraz opracowanego przez autorki wykazu specjalnych przedstawicieli Unii Europejskiej z uwzględnieniem zakresu ich zaangażowania.

Ta cenna pozycja uzupełnia obecne od dwóch lat na rynku opracowanie Leksykon integracji europejskiej w obszarze Sprawiedliwość, Wolność, Bezpieczeństwo. Jednocześnie autorki zakończyły już pracę nad trzecią książką z tego cyklu, która dotyczyć będzie stosunków Unii Europejskiej z państwami trzecimi i organizacjami międzynarodowymi. Nie sposób wyobrazić sobie zapoznania się z tematyką dotyczącą działalności Unii Europejskiej bez sięgnięcia po te publikacje.

MARCIN PIECHOCKI

Poznań

\title{
Aleksandra Kruk, Hans-Dietrich Genscher w polityce wewnętrznej i zagranicznej $R F N$ w latach 1969-1992, Wydawnictwo UNIKAT 2, Katowice 2010, ss. 201.
}

Hans-Dietrich Genscher to postać bez wątpienia niezwykła, znana tak w Republice Federalnej Niemiec, jak i poza jej granicami. Urodzony w roku 1927 niemiecki polityk zasiadał w latach 1965-1998 w Bundestagu. W latach 1969-1974 był ministrem spraw wewnętrznych w rządzie Willego Brandta, a od 1974 do 1992 roku pełnił funkcję ministra spraw zagranicznych. Jego osiemnastoletnie kierowanie Urzędem Spraw Zagranicznych podporządkowane było idei kontynuacji. Pragnął on, by RFN była postrzegana jako państwo demokratyczne. Swymi działaniami nie tylko nadał ton tak wewnętrznej, jak i zagranicznej polityce RFN, ale sprawił, że w świecie polityki i dziennikarstwa zafunkcjonował termin genscheryzm.

Celem, jaki sama autorka zawarła we Wstępie pracy, stało się udowodnienie, iż H.-D. Genscher odegrał, zwłaszcza w latach siedemdziesiątych i osiemdziesiątych XX wieku, czołową rolę na międzynarodowej scenie politycznej. Celowym, zdaniem dr Aleksandry Kruk, stało się zadanie pytania, na ile o skuteczności jego działań decydowały jego własne cechy osobowości, a na ile siła przebicia RFN na arenie międzynarodowej.

2 Tezy opinii i orzeczeń. 
Praca składa się z czterech podporządkowanych podziałowi chronologicznemu rozdziałów, z których pierwszy obejmuje okres od narodzin H.-D. Genschera do początków jego działalności w Bundestagu. Autorka ukazuje proces jego „dojrzewania do polityki”, wiele uwagi poświęcając osobom i wydarzeniom, które go ukształtowały, wskazując m.in. na relacje z rodzicami - Hilde Kreime i Kurtem, a także dziadkami. Opisuje doświadczenie wojny i służbę w Wehrmachcie, a następnie powrót do domu i ucieczkę z NRD. Kolejnym istotnym wydarzeniem staje się wstąpienie H.-D. Genschera do Wolnej Partii Demokratycznej (niem. Freie Deutsche Partei - FDP) oraz poznanie przez niego podczas kampanii wyborezej do Bundestagu w 1953 roku Thomasa Dehlera, który stał się jego ,politycznym mentorem”. Czytelnicy zapoznają się następnie z szeregiem zdarzeń (objęcie funkcji asystenta naukowego frakcji FDP, współtworzenie programu berlińskiego, zatrudnienie na stanowisku dyrektora frakcji FDP, a wreszcie dyrektora generalnego FDP), które doprowadziły do dokonania przez H.-D. Genschera wyboru między polityką a karierą urzędniczą na rzecz tej pierwszej, co oznaczało start w wyborach do Bundestagu 19 września 1965 roku i uzyskanie w nich mandatu. Ostatni fragment tego rozdziału poświęcony jest właśnie działalności poselskiej.

Rozdział drugi koncentruje się na roli H.-D. Genschera w polityce wewnętrznej RFN. Zostaje w nim przedstawiony jako minister spraw wewnętrznych i przewodniczący FDP. Wyjaśniony zostaje zakres jego kompetencji, a istotny staje się kontekst nasilenia działalności terrorystycznej i zamachu podczas olimpiady w Monachium 5 września 1972 roku, w związku z którymi, choć nie odpowiadał formalnie za bezpieczeństwo, polityk z Halle był gotowy złożyć dymisję. Nie została ona przyjęta.

Ważnym aspektem działalności ministra spraw wewnętrznych było uczestnictwo w normalizacji stosunków z państwami Europy Wschodniej, a zwłaszcza dążenie do poprawy relacji z ZSRR, NRD i PRL. W omawianym okresie doszło m.in. do podpisania układu o wzajemnych stosunkach między ZSSR a RFN (12 sierpnia 1971 roku) czy podobnego z PRL (7 grudnia 1970 r.). W ramach Ministerstwa Spraw Wewnętrznych dokonano reformy administracji publicznej. Akcentowano także kwestię ochrony środowiska, powołując m.in. Federalny Urząd Ochrony Środowiska z siedzibą w Berlinie.

W dalszej kolejności, omówione zostało sprawowanie przez ministra i wicekanclerza przewodnictwa w FDP. W odniesieniu do tej partii zaczęto w latach siedemdziesiątych XX wieku używać terminu genscheryzm. Określano ją także często jako „przedsiębiorstwo jednego człowieka". Działalność jej przewodniczącego przedstawiona zostaje przez pryzmat następujących po sobie wyborów, zjazdów, nowych programów. Ukazane zostały jego zmagania o pozycję i autorytet, wskazano także na jego rolę w procesie jednoczenia partii liberalnej.

W rozdziale trzecim omówiona zostaje rola, jaką H.-D. Genscher odegrał w polityce zagranicznej RFN. Oddzielne podrozdziały poświęcone zostały najważniejszym elementom tejże: polityce wschodniej (wobec Polski, Czechosłowacji, Węgier, Rumunii, Bułgarii, Albanii), następnie bezpieczeństwu i działalności na rzecz rozbrojenia, zjednoczeniu Niemiec, udziałowi w budowie jedności europejskiej, a także relacjom Północ-Południe. Autorka podkreśliła, że już w momencie obejmowania urzędu przez nowego ministra, bilans osiągnięć w niemieckiej polityce wschodniej był korzystny. Postępowało odprężenie, zawarte zostały układy z PRL, Czechosłowacją, NRD, ZSRR. Już w trakcie jego urzędowania, doszło do intensyfikacji kontaktów z ZSRR, zwieńczonej parafowaniem 13 września 1990 roku „układu o dobrym sąsiedztwie, partnerstwie i współpracy". Minister uczestniczył także w takich wydarzeniach, jak końcowe spotkanie Konferencji Bezpieczeństwa i Współpracy w Europie czy Światowy Szczyt Ekonomistów w Davos. Propagował hasła kooperacji, opowiadając się m.in. za układami SALT I i SALT II oraz za kontynuacją procesu rozbrojenia. Poparł zawarte 25 czerwea 1988 r. porozumienie między państwami EWG i RWPG o zainicjowaniu oficjalnych relacji. Akcentował znaczenie „Karty Paryskiej”, uznając zawarte w niej postanowienia za czynnik istotny dla uwidocznienia „,nowego początku” w historii Europy. Jego politycznym celem stało się przezwycię- 
żenie podziału Niemiec, a postulat zjednoczenia obecny był w każdym zakresie jego aktywności politycznej. W związku z samym procesem zjednoczeniowym, należy wspomnieć, iż sam H.-D. Genscher dobierał skład delegacji niemieckiej do rokowań 2+4. Podkreślał udział obywateli NRD w uzyskiwaniu jedności i był chwalony za sam sposób prowadzenia rozmów. Istotnym elementem jego koncepcji politycznej stało się, zwłaszcza po 1974 roku, poparcie dla integracji europejskiej. Optował za „Europą obywateli”, „Europą federalną” oraz „Europą solidarności”. W 1990 roku podkreślał, że jest zwolennikiem budowania unii politycznej i gospodarczo-walutowej. Wskazywał także w późniejszym okresie na korzyści z poszerzenia Unii. Działalność ministra spraw zagranicznych przyniosła mu jednak również określenie ,urzędnik Trzeciego Swiata".

Rozdział czwarty stanowi swoistą klamrę. Zostają w nim odtworzone przyczyny dymisji H.-D. Genschera wraz z jego argumentacją. Autorka przywołuje w tym celu zarówno materiały archiwalne, jak i pamiętniki samego polityka. Nie brakuje fragmentu obrazującego krytykę działań ministra spraw zagranicznych po zjednoczeniu Niemiec, szczególnie w odniesieniu do Iraku i byłej Jugosławii, co także stanowiło motyw dymisji. Rozdział zamyka prezentacja międzynarodowych ocen H.-D. Genschera, zarówno politologów (np. Bogdan Koszel, Arnulf Baring, Emil J. Kirchner, Timothy Garton Ash), polityków (m.in. Richard von Weizsäcker, Klaus Kinkel, Walter Scheel, Oskar Lafontaine, Roland Dumas, James A. Baker), jak i dziennikarzy (m.in. Thomas Kielinger, Peter Pragal)

Omawiana publikacja, o której wartości stanowi chociażby otrzymanie przez dr Aleksandrę Kruk Nagrody im. Profesora Piotra Dobrowolskiego, stanowi wielowymiarowe, pełne niuansów studium poświęcone człowiekowi, który niewątpliwie odcisnął piętno na polityce niemieckiej, a wraz z odejściem którego mówiono o końcu pewnej epoki w historii RFN. Należy wspomnieć, iż ta stanowiąca podsumowanie studiów doktoranckich autorki książka jest pierwszą w języku polskim monografią poświęconą temu wybitnemu politykowi.

MARTA ZOBENIAK 